\title{
Bioproduction of Glycolic Acid from Glycolonitrile with a New Bacterial Isolate of Alcaligenes sp. ECU0401
}

\author{
Yu-Cai He $\cdot$ Jian-He Xu $\cdot$ Jin-Huan Su $\cdot$ Li Zhou
}

Received: 13 January 2009 / Accepted: 9 March 2009 /

Published online: 31 March 2009

(C) Humana Press 2009

\begin{abstract}
Alcaligenes sp. ECU0401 has been isolated from soil samples with high nitrilase activity against glycolonitrile using the enrichment culture technique. The preferred carbon/ nitrogen sources and metal ions were sodium acetate, a composite of peptone and yeast extract, and $\mathrm{Cu}^{2+}$, respectively. Glycolic acid was obtained in a yield of $96.5 \%$ after $14 \mathrm{~h}$ of biotransformation from a total of $200 \mathrm{mM}$ glycolonitrile in the mode of sequential addition during the cultivation of Alcaligenes sp. ECU0401 in a 5-L jar fermenter. Fifty micromolars of glycolonitrile could be hydrolyzed in a yield of $94.1 \%$ by resting cells after $36 \mathrm{~h}$. The microbial nitrilase system could hydrolyze various nitriles with high activity, and no amidase activity and glycolic acid were observed in hydrolyzing glycolamide. It significantly exhibited high enantioselectivity in the hydrolysis of mandelonitrile and 2chloromandelonitrile ( $>99.9 \%$ e.e.p). Efficient biocatalyst recycling was achieved as a result of immobilization in glutaraldehyde/polyethylenimine cross-linked carrageenan with immobilized cells exhibiting a biocatalyst productivity of 1,042.2 g glycolic acid per gram dry cell weight after 29 batch recycles.
\end{abstract}

Keywords Nitrilase ·Alcaligenes sp. ECU0401 - Glycolic acid · Glycolonitrile · Immobilization

\section{Introduction}

Nitriles are convenient and synthetically important chemical building blocks because they are widely used in the organic synthesis of compounds such as amides, carboxylic acids,

Y.-C. He • J.-H. Xu $(\bowtie) \cdot$ J.-H. Su • L. Zhou

Laboratory of Biocatalysis and Bioprocessing, State Key Laboratory of Bioreactor Engineering, East China University of Science and Technology, Shanghai 200237, People's Republic of China e-mail: jianhexu@ecust.edu.cn

Y.-C. He

Qingdao Institute of BioEnergy and Bioprocess Technology, Chinese Academy of Sciences, Qingdao 266071, People's Republic of China e-mail: yucaihe2007@yahoo.com.cn 
and their derivatives [1, 2]. However, chemical conversion of nitriles presents several problems: reactions require either strongly basic or acidic media accompanying high energy consumption, and unwanted by-products or large amounts of salts are formed. There is a considerable industrial interest in enzymatic conversion of nitriles owing to the desirability of conducting such conversion under mild conditions. There are two different enzyme systems involved in the hydrolysis of nitrile. The first process is a two-step reaction. The nitrile is converted to the corresponding amide by the nitrile hydratase (EC 4.2.1.84) [3] and then followed by further hydrolysis by an amidase (EC 3.5.1.4) [4], resulting in the production of organic acid and ammonia. The second process involves direct hydrolysis of the nitrile to organic acid with the release of ammonia by a nitrilase (EC 3.5.5.1) [5].

$\alpha$-Hydroxy carboxylic acids are an important class of compounds. Among them, glycolic acid $\left(\mathrm{HOCH}_{2} \mathrm{COOH}\right)$ is known to be the simplest kind of $\alpha$-hydroxy carboxylic compounds. Its properties make it ideal for a broad spectrum of industrial and consumer applications, including use in water well rehabilitation, the leather industry, the oil and gas industry, the laundry, and textile industry. Glycolic acid is also a principal ingredient for household cleaners, industrial cleaners, metals processing, automotive oil additives, $\mathrm{pH}$ controlling, and biodegradable polymers [6-8]. In recent years, much work was done in biotransforming glycolonitrile into glycolic acid [9-16]. Of note, four biocatalysts displaying high glycolonitrile-hydrolyzing activity have been patented: Acidovorax facilis 72W [10], Brevibacterium casei [11], Gordona [12], and Rhodococcus rhodochrous [13]. Specifically, Panova et al. [14] and $\mathrm{Wu}$ et al. [16] described the process for the chemoenzymatic production of glycolic acid, including the bioconversion of glycolonitrile using an immobilized recombinant organism over-expressing an engineered nitrilase enzyme.

The goal of the present work is to screen for a nitrilase-producing microbe from the soil that can be effectively used for bioproduction of glycolic acid from glycolonitrile. With the optimization of culture conditions, a more simplified, practical, and highly productive process for the manufacture of glycolic acid is attempted to be developed. The nitrilaseproducing microbe was further used to hydrolyze a series of nitriles for the biosynthesis of other organic acids through the nitrilase-mediated hydrolysis.

\section{Materials and Methods}

\section{Chemicals}

Glycolonitrile (50 wt.\%, China) was a kind gift from Dr. Yunhai Shi, ECUST, Shanghai, China. Trio- $n$-ctylamine (TOA, technical grade 98.8\%) and 1-octanol (technical grade 99.7\%) were purchased from Jiangsu Feixiang Chemical Co. Ltd. (China). Sulfonated kerosene (technical grade) was purchased from Suzhou Wenyi Petrochemical Co. Ltd. (China), in which the initial distillated boiling point is greater than $185^{\circ} \mathrm{C}$. All of them were used without further purification. All other chemicals were also from a commercial source and of reagent grade.

\section{Microorganism, Growth, and Biotransformation Conditions}

Nitrilase-producer strains were obtained through a two-step enrichment cultivation procedure on minimal salt medium (MSM) of the following composition (per liter of tap water): glycerol $15 \mathrm{~g}, \mathrm{KH}_{2} \mathrm{PO}_{4} 2 \mathrm{~g}, \mathrm{NaCl} 1 \mathrm{~g}, \mathrm{MgSO}_{4} 0.2 \mathrm{~g}, 0.03 \mathrm{~g} \mathrm{FeSO}$, acetonitrile $2 \mathrm{mM}$ or glycolonitrile $2 \mathrm{mM}$, trace elements solution $2 \mathrm{~mL}$, and vitamin solution $2 \mathrm{~mL}, \mathrm{pH}$ 
7.2 [17]. The strains, after being grown on solid medium (15 g glycerol, $10 \mathrm{~g}$ peptone, $5 \mathrm{~g}$ yeast extract, $2 \mathrm{~g} \mathrm{KH}_{2} \mathrm{PO}_{4}, 1 \mathrm{~g} \mathrm{NaCl}, 0.2 \mathrm{~g} \mathrm{MgSO}_{4}, 0.03 \mathrm{~g} \mathrm{FeSO}_{4}$, and $15 \mathrm{~g}$ agar in $1,000 \mathrm{~mL}$ tap water, $\mathrm{pH} 7.0$ ) for $48 \mathrm{~h}$, were first pre-cultivated in $6 \mathrm{~mL}$ growth medium (solid medium without agar) for $15 \mathrm{~h}$, then inoculated into 1,000 mL Erlenmeyer flasks containing $194 \mathrm{~mL}$ of the growth medium and shaken at $30^{\circ} \mathrm{C}$ and $160 \mathrm{rpm}$. After $48 \mathrm{~h}$ of cultivation, cells were harvested from the culture broth, washed, and resuspended in $100 \mathrm{mM}$ potassium phosphate buffer (pH6.5) containing $20 \mathrm{mM}$ glycolonitrile.

Fed-batch culture experiment was conducted using a 5-L fermenter (Shanghai Guoqiang Equipment Company, China). A pre-seed culture was prepared by inoculating a single colony of Alcaligenes sp. ECU0401 into 1,000 mL Erlenmeyer flask containing $150 \mathrm{~mL}$ growth medium and incubated in flask shaker at $30^{\circ} \mathrm{C}$ and $160 \mathrm{rpm}$ for $15 \mathrm{~h}$. The culture was transferred into a 5-L fermenter with $3 \mathrm{~L}$ of the liquid medium (the optimized medium plus $50 \mathrm{mM}$ glycolonitrile). During all the experiments, the agitation speed and airflow rate were adjusted as required to keep the dissolved oxygen level above $30 \%$ relative to saturation. The temperature was kept at $30^{\circ} \mathrm{C}$ and the $\mathrm{pH}$ of the medium was controlled at pH6.0 by the automatic addition of $\mathrm{H}_{2} \mathrm{SO}_{4}$ and $\mathrm{NaOH}$. Defoamer GPE $(0.03 \%, v / v)$ was used as an antifoam agent to prevent foaming.

\section{Bioconversion Process with Resting Cells}

Hydrolysis of nitrile was determined using the resting cells of Alcaligenes sp. ECU0401. The harvested cells were washed twice with $20 \mathrm{~mL}$ phosphate buffer $(\mathrm{pH} 6.5,100 \mathrm{mM})$ and then resuspended in the same buffer. The reaction, consisting of a certain concentration of substrate $(10-100 \mathrm{mM})$ and $2.0 \mathrm{~g}$ wet weight (ca. $0.304 \mathrm{~g}$ dry cell weight) of resting cells in $20 \mathrm{~mL}$ phosphate buffer $(\mathrm{pH} 6.5,100 \mathrm{mM})$, was carried out at $30^{\circ} \mathrm{C}$ and $160 \mathrm{rpm}$. The bioconversion process was monitored with high performance liquid chromatography (HPLC) by withdrawing $0.2 \mathrm{~mL}$ of samples at fixed time intervals. The reaction was stopped by adding $20 \mu \mathrm{L}$ of $2 \mathrm{M} \mathrm{HCl}$ to a $180-\mu \mathrm{L}$ sample followed by centrifugation. The clear supernatant, diluted with buffer when necessary, was assayed for organic acid concentration by HPLC.

\section{Analytical Methods}

Biomass concentrations were estimated with a UV-Vis spectrophotometer (Unico UV2100 , China) at $600 \mathrm{~nm}$ by measuring the optical density of the cultures.

The nitrile hydrolysis process was monitored with HPLC by withdrawing $0.2 \mathrm{~mL}$ each of the samples at fixed time intervals. The samples were centrifuged in an Eppendorf centrifuge at $12,000 \times \mathrm{g}$ for $6 \mathrm{~min}$, and the supernatants were assayed by analytical HPLC (LC-10AT VP, Shimadzu Co., Japan). A $\mathrm{C}_{18}$ reversed-phase column (Shim-pack VP-ODS, Shimadzu Co., Japan) was used to identify glycolic acid which was detected spectrophotometrically at $215 \mathrm{~nm}$. Twenty-micromolar $\mathrm{KH}_{2} \mathrm{PO}_{4}(\mathrm{pH} 2.5)$ in $\mathrm{H}_{2} \mathrm{O}$ with a flow rate of $0.5 \mathrm{~mL} / \mathrm{min}$ was used as an eluent. The retention time for glycolic acid was $7.12 \mathrm{~min}$.

In the process of glycolonitrile hydrolysis, glyoxylic acid, formic acid, and oxalic acid may be produced as by-products by oxidation of glycolic acid with microbial dehydrogenases. Since the structures of these four substances are similar, qualitative and quantitative analyses are often difficult to achieve simultaneously. Ion chromatography can be employed to determine these acid species [18]. Based on ion chromatography technology, we have developed a new method that combines ion chromatography with a conductivity detector to separate and determine the substances of glycolic acid, glyoxylic acid, formic acid, and oxalic acid. All systems and components for ionic analysis were from Dionex 
(Sunnycale, CA, USA). The hardware used for these analyses consisted of an ICS-1500 ion chromatography equipped with an isocratic pump, a conductivity detector DS6, a reagentfree controller, and an eluent generator. Data were acquired by using Chromeleon 6.8 software. The eluent was $8 \mathrm{mM} \mathrm{KOH}$. The eluent flow rate was set at $1.0 \mathrm{~mL} / \mathrm{min}$ with an injection volume of $100 \mu \mathrm{L}$. For the analytical separation, an IonPac AS11HC $(50 \mathrm{~mm} \times \varphi$ $4 \mathrm{~mm})$ guard column and IonPac AS11HC (250 $\mathrm{mm} \times \varphi 4 \mathrm{~mm})$ analytical column were used. In addition, an ASRS-ULTR (4 $\mathrm{mm}$ ) suppressor was utilized in the recycle mode. Retention times for glycolic acid, formic acid, glyoxylic acid, and oxalic acid were 4.50, $5.03,7.62$, and $18.81 \mathrm{~min}$, respectively.

\section{Nitrilase Assays}

Nitrilase activity in resting cells was measured by using the ammonia release assay of Fawcett and Scott [19]. One unit of activity is defined as the amount of enzyme required to catalyze the formation of $1 \mu \mathrm{mol}$ ammonia per minute at $30^{\circ} \mathrm{C}$ under standard assay conditions. All assays were performed in triplicate.

\section{Culture Condition Optimization}

The optimization experiments for culture conditions were carried out under different cultivation conditions (initial medium $\mathrm{pH}$ ) and on different media mainly composed of carbon/nitrogen sources, metal ions, and inducers. The conditions for glycolic acid preparation were optimized by measuring the turbidity $\left(\mathrm{OD}_{600}\right)$ of the culture broth and the concentration of glycolic acid. A basal medium, containing $10 \mathrm{~g}$ glycerol, $10 \mathrm{~g}$ peptone, $5 \mathrm{~g}$ yeast extract, $2 \mathrm{~g} \mathrm{KH}_{2} \mathrm{PO}_{4}, 1 \mathrm{~g} \mathrm{NaCl}, 0.2 \mathrm{~g} \mathrm{MgSO}_{4}$ and $0.03 \mathrm{~g} \mathrm{FeSO}_{4} \cdot 7 \mathrm{H}_{2} \mathrm{O}$ in $1,000 \mathrm{~mL}$ tap water (pH7.0), was employed unless otherwise stated.

\section{Effects of Reaction $\mathrm{pH}$ and Temperature}

The effect of reaction $\mathrm{pH}$ on the glycolonitrile hydrolysis activity was determined using reaction mixtures adjusted to specified $\mathrm{pH}$ values as follows: $\mathrm{pH} 4.0-6.0,100 \mathrm{mM}$ citric acid- $\mathrm{Na}_{3}$ citrate buffer; $\mathrm{pH} 6.0-8.0,100 \mathrm{mM} \mathrm{K \textrm {K } _ { 2 }} \mathrm{PO}_{4}-\mathrm{K}_{2} \mathrm{HPO}_{4}$ buffer, under otherwise similar conditions. The effect of reaction temperature on the glycolonitrile hydrolysis activity was examined at different temperatures from 20 to $50^{\circ} \mathrm{C}$ by assaying their activities at the respective temperatures, under otherwise similar conditions.

\section{Hydrolysis of Glycolamide and Various Nitriles by Alcaligenes sp. ECU0401}

Hydrolysis of glycolamide and various nitriles (acrylonitrile, acetonitrile, 2-chloromandelonitrile, diaminomaleonitrile, glycolonitrile, iminodiacetonitrile, mandelonitrile, and phenylacetonitrile) was determined using the resting cells of Alcaligenes sp. ECU0401. The reactions were performed at $30^{\circ} \mathrm{C}$ and $160 \mathrm{rpm}$ in $100 \mathrm{~mL}$ potassium phosphate buffer $(100 \mathrm{mM}$, pH6.5) with $10.0 \mathrm{~g}$ wet weight of resting cells, and the substrate concentrations were $20 \mathrm{mM}$, respectively.

Immobilization of Cells and Repeated Batch Biosynthesis of Glycolic Acid by Immobilized Cells

The immobilization protocol started with heating a $10.0 \%$ dry cell weight (dcw) suspension in $100 \mathrm{mM}$ phosphate buffer (pH6.5) to $50^{\circ} \mathrm{C}$ prior to mixing with a 5.0 -wt. $\%$ carrageenan 
solution at $50^{\circ} \mathrm{C}$, and the resulting $50^{\circ} \mathrm{C}$ cell/carrageenan suspension was immediately dripped into a potassium bicarbonate buffer to produce the catalyst beads (ca. approximately $2.5 \mathrm{~mm}$ diameter). The immobilized cells $(4.0 \% \mathrm{dcw}$ in $3.0 \%$ carrageenan beads) were subsequently chemically cross-linked with glutaraldehyde (GA) and polyethylenimine (PEI), producing a physically robust immobilized cell catalyst with acceptable gel strength for use in the batch biocatalytic reaction.

To assess the reuse potential of the alginate entrapped cells, repeated batch transformations of glycolonitrile were carried out under the same experimental conditions described for the first cycle. The reaction, consisting of certain concentration of substrate $(20 \mathrm{mM})$ and $10.0 \mathrm{~g}$ of immobilized beads containing $4.0 \%$ (dcw) cells in $100 \mathrm{~mL}$ phosphate buffer (pH6.5, $100 \mathrm{mM}$ ), was carried out at $30^{\circ} \mathrm{C}$ and $160 \mathrm{rpm}$. After each cycle of complete conversion, the beads were washed with physiological saline $(0.85 \% \mathrm{NaCl}, w / v)$ and transferred into a fresh 100-mM phosphate buffer ( $\mathrm{pH} 6.5$ ).

Purification of Glycolic Acid from the Hydrolyzates Obtained from Hydrolysis of Glycolonitrile by Immobilized Cells

The extractant was prepared with components of $1.38 \mathrm{~mol} / \mathrm{L}$ TOA, $0.63 \mathrm{~mol} / \mathrm{L} 1$-octanol, and $30 \%$ kerosene in a volume of the total organic phase [6]. The hydrolyzates containing glycolic acid obtained from glycolonitrile hydrolysis by immobilized cells were adjusted to $\mathrm{pH}$ 1.0. For liquid-liquid equilibrium experiments, equivalent volumes of hydrolyzates solution and an organic extractant were stirred in a $250-\mathrm{mL}$ jacketed glass separatory funnel at $25^{\circ} \mathrm{C}$ for $0.5 \mathrm{~h}$, which preliminary tests demonstrated to be the sufficient time to establish the equilibrium between two the phases. Thereafter, the mixture was kept at the same temperature for another $0.5 \mathrm{~h}$, which was sufficient for a complete phase separation [6]. The loaded organic extractant was regenerated by using deionized water as the back extractant at $85^{\circ} \mathrm{C}$. After back extraction for four times using deionized water, the solution of glycolic acid collected was concentrated under reduced pressure. Then, the concentrated glycolic acid was assayed with HLPC and ion chromatography.

\section{Results and Discussion}

\section{Screening of Microorganisms}

Microorganisms were isolated from soil by enrichment culture on MSM. One strain marked as ECU0401 that showed higher nitrilase activity and yield of glycolic acid was finally chosen and identified according to its sequence of $16 \mathrm{~S}$ ribosomal DNA (rDNA). The sequence data were deposited in Genbank database (accession number: EF535732). 16S rDNA gene was amplified by two primers of 5'-A GAG TTT GAT CCT GGC TCA G-3' and 5'T ACG GCT ACC TTG TTA CGA C-3' [20], and the strain ECU0401 was consequently named as Alcaligenes sp. ECU0401 [17]. The nitrilase gene from Alcaligenes sp. ECU0401 has been cloned, sequenced, and expressed in E. coli in an active form with excellent yield [21]. The predicted amino acid sequence of Alcaligenes sp. ECU0401 nitrilase was compared with that of Alcaligenes faecalis JM3 [22], and there was a $89.0 \%$ match of amino acids between the two nitrilases (data not shown). Only glycolic acid was produced by Alcaligenes sp. ECU0401, without any detectable glyoxylic acid, formic acid, or oxalic acid as a byproduct. Therefore, Alcaligenes sp. ECU0401 is a promising nitrilase-producer strain with higher nitrilase activity for transforming glycolonitrile into glycolic acid. 
Optimization of Medium Composition and Culture Condition

\section{Effects of Carbon Source and Nitrogen Source}

Obviously, the medium composition has profound effects on cell growth and enzyme activity. The optimum carbon/nitrogen sources for growth and enzyme formation were tested by growing Alcaligenes sp. ECU0401 in the medium of initial pH7.0 at $30^{\circ} \mathrm{C}$ on a rotary shaker $(120 \mathrm{rpm})$. Various carbon sources, all at a final concentration of $10 \mathrm{~g} / \mathrm{L}$, were tested for their effects on biomass production and specific enzyme activity. Lower enzyme activities were obtained with glycerol, glucose, mannitol, and maltose, although they supported well the cell growth. Inorganic carbon sources, such as ammonium acetate and sodium acetate, did support nitrilase production and growth of Alcaligenes sp. ECU0401 (Table 1). Sodium acetate proved to be the most suitable carbon source as it gave higher biomass as well as specific activity, and $10 \mathrm{~g} / \mathrm{L}$ of sodium acetate was found to be an optimum composition of carbon source (data not shown).

Nitrogen source is an important ingredient of the medium for a microorganism. Using sodium acetate $(10 \mathrm{~g} / \mathrm{L})$ as the carbon source, various nitrogen sources, including $\left(\mathrm{NH}_{4}\right)_{2} \mathrm{SO}_{4}, \mathrm{NH}_{4} \mathrm{Cl}, \mathrm{CH}_{3} \mathrm{COONH}_{4}$, urea, acetonitrile, glycolonitrile, phenylacetonitrile, peptone, beef extract, and yeast extract, were added at a final concentration of $5 \mathrm{~g} / \mathrm{L}$ to the medium. As a result, various nitriles did not support biomass, but they could increase the enzyme activity (Table 2). Ammonium acetate and peptone gave higher specific activity, while peptone afforded higher cell mass production than ammonium acetate and was therefore chosen for further studies. Using a composite of peptone and yeast extract as the nitrogen source, the nitrilase activity and biomass increased sharply, and the composite of peptone $(10 \mathrm{~g} / \mathrm{L})$ plus yeast extract $(5 \mathrm{~g} / \mathrm{L})$ was found to be an optimum composition of nitrogen sources.

Table 1 Effects of various carbon sources on the cell growth and nitrilase production by Alcaligenes sp. ECU0401.
${ }^{\text {a }}$ Basal medium without carbon sources

\begin{tabular}{|c|c|c|}
\hline Carbon source & $\mathrm{OD}_{600}$ & $\begin{array}{l}\text { Specific activity } \\
\left(\mu \mathrm{mol} \min ^{-1} \mathrm{~g}^{-1}\right)\end{array}$ \\
\hline Control $^{\mathrm{a}}$ & $0.45 \pm 0.02$ & $555 \pm 7.8$ \\
\hline Sucralose & $6.47 \pm 0.08$ & $169 \pm 10.4$ \\
\hline Phenylacetonitrile & $1.01 \pm 0.11$ & $229 \pm 2.6$ \\
\hline Glucose & $10.58 \pm 0.11$ & $385 \pm 5.9$ \\
\hline Starch & $0.40 \pm 0.11$ & $434 \pm 3.9$ \\
\hline Galactose & $5.42 \pm 0.53$ & $475 \pm 6.5$ \\
\hline Mannitol & $11.61 \pm 0.08$ & $493 \pm 8.5$ \\
\hline Lactose & $5.52 \pm 0.02$ & $524 \pm 5.9$ \\
\hline Glycerol & $13.27 \pm 0.74$ & $527 \pm 7.8$ \\
\hline Maltose & $11.93 \pm 0.04$ & $556 \pm 5.9$ \\
\hline Dextrin & $8.04 \pm 0.04$ & $583 \pm 15.6$ \\
\hline Fructose & $7.88 \pm 0.04$ & $588 \pm 11.1$ \\
\hline Acetonitrile & $5.48 \pm 0.11$ & $649 \pm 5.2$ \\
\hline Glycolonitrile & $0.42 \pm 0.02$ & $663 \pm 7.2$ \\
\hline Ammonium acetate & $5.75 \pm 0.13$ & $741 \pm 7.2$ \\
\hline Sodium acetate & $7.06 \pm 0.32$ & $975 \pm 13.7$ \\
\hline
\end{tabular}


Table 2 Effects of various nitrogen sources on the cell growth and nitrilase production by Alcaligenes sp. ECU0401.
${ }^{\text {a }}$ Basal medium $(\mathrm{g} / \mathrm{L}): 10$ sodium acetate, $2 \mathrm{KH}_{2} \mathrm{PO}_{4}, 1 \mathrm{NaCl}, 0.2$ $\mathrm{MgSO}_{4}, 0.03 \mathrm{FeSO}_{4}$

\begin{tabular}{|c|c|c|}
\hline Nitrogen source & $\mathrm{OD}_{600}$ & $\begin{array}{l}\text { Specific activity } \\
\left(\mu \mathrm{mol} \mathrm{min} \mathrm{mi}^{-1}\right)\end{array}$ \\
\hline Control $^{\mathrm{a}}$ & $0.99 \pm 0.06$ & $142 \pm 8.5$ \\
\hline Ammonium nitrate $(5 \mathrm{~g} / \mathrm{L})$ & $1.24 \pm 0.13$ & $46 \pm 5.9$ \\
\hline Urea $(5 \mathrm{~g} / \mathrm{L})$ & $1.18 \pm 0.02$ & $74 \pm 4.6$ \\
\hline Yeast extract $(5 \mathrm{~g} / \mathrm{L})$ & $4.26 \pm 0.63$ & $94 \pm 12.4$ \\
\hline Beef extract $(5 \mathrm{~g} / \mathrm{L})$ & $6.11 \pm 0.11$ & $97 \pm 11.7$ \\
\hline Phenylacetonitrile $(5 \mathrm{~g} / \mathrm{L})$ & $0.36 \pm 0.04$ & $392 \pm 9.1$ \\
\hline Glycolonitrile $(5 \mathrm{~g} / \mathrm{L})$ & $0.34 \pm 0.06$ & $595 \pm 19.5$ \\
\hline Acetonitrile $(5 \mathrm{~g} / \mathrm{L})$ & $0.69 \pm 0.06$ & $623 \pm 22.1$ \\
\hline Ammonium sulfate $(5 \mathrm{~g} / \mathrm{L})$ & $1.39 \pm 0.13$ & $670 \pm 5.2$ \\
\hline $40 \mathrm{~g} / \mathrm{L}$ peptone $+20 \mathrm{~g} / \mathrm{L}$ yeast extract & $11.01 \pm 0.06$ & $709 \pm 32.5$ \\
\hline $\begin{array}{l}2.5 \mathrm{~g} / \mathrm{L} \text { peptone }+2.5 \mathrm{~g} / \mathrm{L} \\
\text { yeast extract }\end{array}$ & $5.38 \pm 0.06$ & $787 \pm 35.8$ \\
\hline $5 \mathrm{~g} / \mathrm{L}$ peptone $+2.5 \mathrm{~g} / \mathrm{L}$ yeast extract & $5.52 \pm 0.06$ & $813 \pm 44.9$ \\
\hline $10 \mathrm{~g} / \mathrm{L}$ peptone $+5 \mathrm{~g} / \mathrm{L}$ beef extract & $6.87 \pm 0.06$ & $845 \pm 35.8$ \\
\hline Peptone $(5 \mathrm{~g} / \mathrm{L})$ & $4.28 \pm 0.04$ & $910 \pm 39.7$ \\
\hline $20 \mathrm{~g} / \mathrm{L}$ peptone $+10 \mathrm{~g} / \mathrm{L}$ yeast extract & $7.94 \pm 0.06$ & $930 \pm 53.3$ \\
\hline $10 \mathrm{~g} / \mathrm{L}$ peptone $+5 \mathrm{~g} / \mathrm{L}$ yeast extract & $7.06 \pm 0.32$ & $975 \pm 13.7$ \\
\hline Ammonium acetate $(5 \mathrm{~g} / \mathrm{L})$ & $3.68 \pm 0.04$ & $1,216 \pm 57.9$ \\
\hline
\end{tabular}

\section{Effects of Metal Ions}

In the literature, there were reports where the addition of metal ions reduced the nitrilase activity as well as growth of the organism. For instance, $\mathrm{Cu}^{2+}$ caused strong inhibition of cell growth, while $\mathrm{Co}^{2+}$ resulted in marked decrease in nitrilase production by $R$. rhodochrous $\mathrm{J} 1$ [23]. The effects of various metal ions, including $\mathrm{CaCl}_{2}, \mathrm{CoCl}_{2} \cdot 6 \mathrm{H}_{2} \mathrm{O}$, $\mathrm{CuSO}_{4}, \mathrm{FeCl}_{3} \cdot \mathrm{H}_{2} \mathrm{O}, \mathrm{FeSO}_{4} \cdot 7 \mathrm{H}_{2} \mathrm{O}, \mathrm{KH}_{2} \mathrm{PO}_{4}, \mathrm{MgCl}_{2}, \mathrm{MgSO}_{4}, \mathrm{MnCl}_{2}, \mathrm{NaCl}, \mathrm{NiCl}_{2} \cdot 7 \mathrm{H}_{2} \mathrm{O}$, and $\mathrm{ZnCl}_{2}$, on the nitrilase formation by Alcaligenes sp. ECU0401 were investigated. All the inorganic compounds were added separately to the medium to final concentrations of 0.1 and $1.0 \mathrm{mM}$ (data not shown), respectively. The addition of $\mathrm{Co}^{2+}, \mathrm{Mn}^{2+}$, and $\mathrm{Ni}^{2+}$ caused a marked decrease in the biomass production as well as nitrilase production by Alcaligenes sp. ECU0401. Other metal ions supported neither biomass nor the enzyme production, except $\mathrm{Cu}^{2+}, \mathrm{K}^{+}, \mathrm{Mg}^{2+}$, and $\mathrm{Na}^{+}$which supported higher biomass and enzyme production compared to the medium devoid of any metal ions. Finally, $\mathrm{CuSO}_{4}(0.08 \mathrm{~g} / \mathrm{L})$, $\mathrm{KH}_{2} \mathrm{PO}_{4}(3 \mathrm{~g} / \mathrm{L}), \mathrm{MgSO}_{4}(0.3 \mathrm{~g} / \mathrm{L})$, and $\mathrm{NaCl}(1.5 \mathrm{~g} / \mathrm{L})$ were included in the optimized medium.

\section{Effects of Initial $\mathrm{pH}$}

Composition of the medium and other physicochemical parameters were optimized by the classical approach for searching the most important determinants affecting the enzyme production by the Alcaligenes sp. ECU0401. Optimization of the initial medium $\mathrm{pH}$ revealed a very unique trend. Alcaligenes sp. ECU0401 was able to grow and showed sufficient enzyme activity within a broad $\mathrm{pH}$ range (6.0-9.0). The highest growth as well as enzyme production was obtained at pH6.0 (data not shown). It was reported that the 
Pseudomonas putida gave highest growth and enzyme production when the $\mathrm{pH}$ of the medium was initially adjusted to 6.0 [24]. Therefore, the optimum medium was composed of $10 \mathrm{~g} / \mathrm{L}$ sodium acetate, $10 \mathrm{~g} / \mathrm{L}$ peptone, $5 \mathrm{~g} / \mathrm{L}$ yeast extract, $3 \mathrm{~g} / \mathrm{L} \mathrm{KH}_{2} \mathrm{PO}_{4}, 1.5 \mathrm{~g} / \mathrm{L} \mathrm{NaCl}$, $0.3 \mathrm{~g} / \mathrm{L} \mathrm{MgSO}_{4}$, and $0.08 \mathrm{~g} / \mathrm{L} \mathrm{CuSO}_{4}$, at $\mathrm{pH} 6.0$.

\section{Effects of Inducers}

Nitrilases are generally known to be inducible in nature during microbial cultivation [25], typically executed by substrates, products, or their structural analogues. A variety of potential inducers $(2 \mathrm{mM})$, including glycolic acid, various nitriles, and $\varepsilon$-caprolactam, were used to examine the induction efficiency for Alcaligenes sp. ECU0401. Acetonitrile, acrylonitrile, glycolonitrile, phenylacetonitrile, and diaminomaleonitrile support abundant growth, while $\alpha$-aminoropionitrile lowered both the cell mass and activity production. Among them, $\varepsilon$-caprolactam could enhance the activity from 975 to $1,883 \mathrm{U} /(\mathrm{g} \mathrm{dcw}$; Table 3), which was a hyper-inducer of nitrilase in $R$. rhodochrous J1 [26]. It was reported that nitrilase in A. faecalis ATCC 8750 is an induced enzyme [27]. However, in our study, Alcaligenes sp. ECU0401 cells grown in the absence of any inducer did exhibit higher nitrilase activity, indicating the constitutive nature of the enzyme. In the following study, no inducer was added into the culture system.

\section{Fed-Batch Bioconversion of Glycolonitrile with Growth Cells}

Fed-batch bioconversion of glycolonitrile with growth cells may effectively produce glycolic acid. Figure 1 showed the time course for the glycolic acid production with sequential addition of glycolonitrile during the cultivation of Alcaligenes sp. ECU0401 in a 5-L jar fermenter containing 1.5 L liquid medium composed of $50 \mathrm{mM}$ glycolonitrile, $10 \mathrm{~g} / \mathrm{L}$ sodium acetate, $10 \mathrm{~g} / \mathrm{L}$ peptone, $5 \mathrm{~g} / \mathrm{L}$ yeast extract, $3 \mathrm{~g} / \mathrm{L} \mathrm{KH}_{2} \mathrm{PO}_{4}, 1.5 \mathrm{~g} / \mathrm{L} \mathrm{NaCl}, 0.3 \mathrm{~g} / \mathrm{L}$ $\mathrm{MgSO}_{4}$, and $0.08 \mathrm{~g} / \mathrm{L} \mathrm{CuSO}_{4}$ at $\mathrm{pH} 6.0,30^{\circ} \mathrm{C}$ and $300 \mathrm{rpm}$. The cultivation was conducted for $24 \mathrm{~h}$. By fed-batch culture, glycolic acid was successfully produced in a 5-L fermenter with a $96.5 \%$ yield from a total of $200 \mathrm{mM}$ glycolonitrile after $14 \mathrm{~h}$ of biotransformation. After $24 \mathrm{~h}$ of transformation, $98.2 \%$ yield was obtained. Based on the above experiment,

Table 3 Effects of various inducers on the cell growth and nitrilase production by Alcaligenes sp. ECU0401.

\footnotetext{
${ }^{\mathrm{a}}$ No inducer
}

\begin{tabular}{lcc}
\hline Inducer $(2 \mathrm{mM})$ & $\mathrm{OD}_{600}$ & $\begin{array}{c}\text { Specific activity } \\
\left(\mu \mathrm{mol} \mathrm{min} \mathrm{g}^{-1}\right)\end{array}$ \\
\hline Control $^{\mathrm{a}}$ & $7.06 \pm 0.32$ & $975 \pm 13.7$ \\
Acrylonitrile $^{-1}$ & $8.01 \pm 0.11$ & $70 \pm 9.8$ \\
$\alpha$-Aminoropionitrile & $4.12 \pm 0.44$ & $493 \pm 9.1$ \\
Iminodiacetonitrile & $7.77 \pm 0.44$ & $748 \pm 4.6$ \\
Diaminomaleonitrile & $8.69 \pm 0.88$ & $780 \pm 5.2$ \\
Acetonitrile & $8.74 \pm 0.88$ & $891 \pm 16.9$ \\
4-Chloro-3-hydroxybutyronitrile & $7.52 \pm 2.21$ & $936 \pm 13.7$ \\
2,3-Pyrazinedicarbonitrile & $4.14 \pm 0.88$ & $956 \pm 5.9$ \\
Glycolic acid & $7.15 \pm 0.12$ & $982 \pm 7.2$ \\
Glycolonitrile & $8.48 \pm 0.44$ & $1,001 \pm 11.7$ \\
Phenylacetonitrile & $8.19 \pm 0.44$ & $1,216 \pm 18.2$ \\
$\varepsilon$-Caprolactam & $7.67 \pm 0.22$ & $1,883 \pm 12.4$ \\
\hline
\end{tabular}


Fig. 1 Time courses for the preparation of glycolic acid with sequential addition of glycolonitrile during the cultivation of Alcaligenes sp. ECU0401. Symbols: downward arrows, addition of $50 \mathrm{mM}$ glycolonitrile at each time; filled circles, glycolic acid; empty circles, $\mathrm{OD}_{600}$

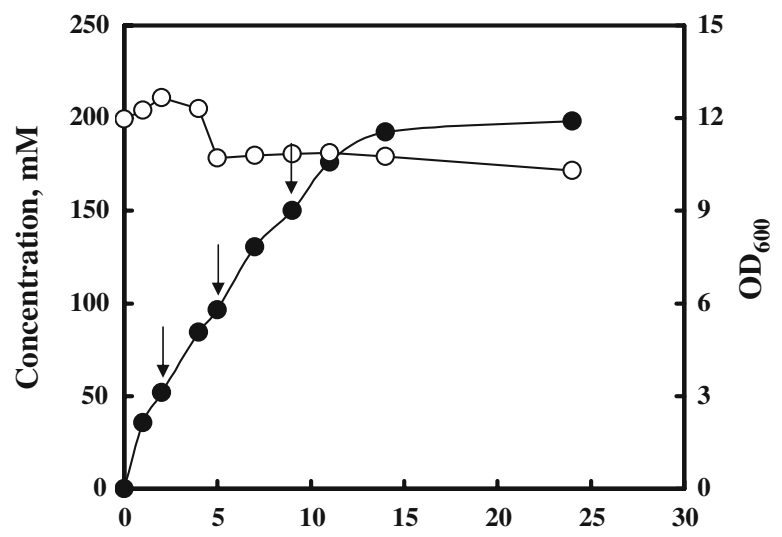

Biotransformation time, $h$

fed-batch bioconversion of glycolonitrile with growth cells was a potential process for the production of glycolic acid, if the process steps to separate glycolic acid from the other components of the fermentation broth were economical.

Catalytic Hydrolysis of Nitriles with Resting Cells

\section{Effects of Reaction $\mathrm{pH}$ and Temperature on Biotransformation Activity}

The hydrolysis reaction was carried out in $100 \mathrm{mM}$ buffers of various $\mathrm{pH}$ values. As shown in Fig. 2a, the hydrolysis rate exhibited a maximum at $\mathrm{pH} 6.5$. The effect of temperature on nitrilase activity is shown in Fig. 2b. The hydrolysis rate increased with a rise in temperature, reaching a maximum at $30^{\circ} \mathrm{C}$. At temperatures above $30^{\circ} \mathrm{C}$, the hydrolysis rate decreased considerably, possibly due to thermal deactivation of enzymes in the cells during the reaction. The optimal reaction conditions of $\mathrm{pH} 6.5$ and $30^{\circ} \mathrm{C}$ were employed for the following experiments. It was reported that the optimal reaction temperature and reaction $\mathrm{pH}$ value for $A$. faecalis JM3 nitrilase were found to be $45^{\circ} \mathrm{C}$ and 7.5 , respectively [28].

\section{Hydrolysis of Glycolamide and Various Nitriles by Alcaligenes sp. ECU0401 with Resting Cells}

The ability of resting cells to catalyze the hydrolysis of glycolamide and various nitriles was examined (Table 4). No amidase activity and glycolic acid were observed in hydrolyzing glycolamide. Nitrilase from Alcaligenes sp. ECU0401 had broad substrate specificity in hydrolyzing both aromatic and aliphatic nitriles. As for aliphatic dinitriles, diaminomaleonitrile could be hydrolyzed with high activity by Alcaligenes sp. ECU0401, and the substrate could be hydrolyzed by $R$. rhodochrous K22 with low activity [29]. However, no nitrilase activity was observed in hydrolyzing iminodiacetonitrile by Alcaligenes sp. ECU0401, and A. faecalis JM3 nitrilase was completely inactive against iminodiacetonitrile [28]. The observation was unlike nitrilase in $R$. rhodochrous $\mathrm{K} 22$ in which iminodiacetonitrile was hydrolyzed with high activity [29]. The microbial nitrilase system also exhibited significantly high enantioselectivity in the hydrolysis of racemic mandelonitrile and 2-chloromandelonitrile $(>99.9 \%$ e.e.p). Steric hindrance of the nitrilase from Alcaligenes sp. ECU0401 by the $\mathrm{Cl}$ atom of the 2-chloromandelonitrile probably 
Fig. 2 Effects of reaction $\mathrm{pH}$ and reaction temperature on the biotransformation activity. a Effects of reaction $\mathrm{pH}$ on the biotransformation activity. Symbols: diamonds, $\mathrm{pH} 4.0-6.0,100 \mathrm{mM}$ citric acid- $\mathrm{Na}_{3}$ citrate buffer; squares, pH6.0-8.0, $100 \mathrm{mM}$ $\mathrm{KH}_{2} \mathrm{PO}_{4}-\mathrm{K}_{2} \mathrm{HPO}_{4}$ buffer;

b effects of reaction temperature on the biotransformation activity by Alcaligenes sp. ECU0401
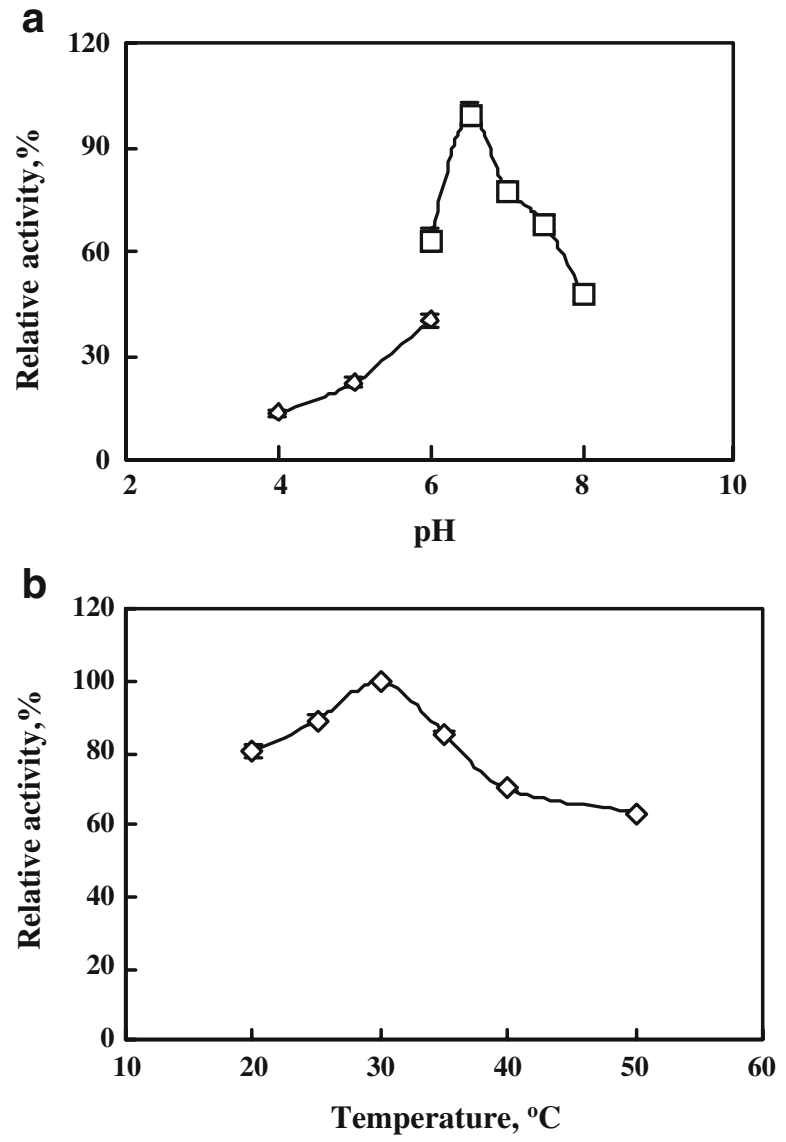

influenced the rate of hydrolysis. $(R)-(-)$-Mandelic acid and its derivatives are a class of chiral synthons for the production of various pharmaceuticals, such as semi-synthetic penicillins, cephalosporins, antiobesity agents, and antitumor agents, etc., and are also used as a chiral resolving agent [30]. Biocatalytic methods for economically producing optically active enantiomers of hydroxy acids under mild conditions are of great interest. Biosynthesis of optically active $(R)-(-)$-mandelic acid and its derivatives from corresponding racemic nitriles with Alcaligenes sp. ECU0401 is still in progress.

\section{Bioconversion of Glycolonitrile with Resting Cells}

The nitrilase in Alcaligenes sp. ECU0401 preferentially hydrolyzed glyconitrile to produce glycolic acid (Table 4). Hydrolysis of glyconitrile was determined using the resting cells of Alcaligenes sp. ECU0401, and the substrate concentrations were 10, 50, and $100 \mathrm{mM}$, respectively. Figure 3 showed the time course for the glycolic acid production with resting cells. Ten micromolars of glycolonitrile could be completely hydrolyzed after $12 \mathrm{~h}$, and $50 \mathrm{mM}$ of glycolonitrile could be hydrolyzed in a yield of $94.1 \%$ after $36 \mathrm{~h}$. Resting cells could tolerate $100 \mathrm{mM}$ of substrate, and glycolic acid could be obtained in a yield of $73.6 \%$ after $36 \mathrm{~h}$. In the time course of glycolic acid production from glycolonitrile, no glycolamide was found in the hydrolysis. 
Table 4 Hydrolysis of various nitriles by Alcaligenes sp. ECU0401.

\begin{tabular}{lllll}
\hline Entry & Substrate & Relative activity $(\%)$ & Conversion $(\%)^{\mathrm{a}, \mathrm{b}}$ & e.e. $(\%)$ \\
\hline 1 & Glycolonitrile & 100 & 100 & - \\
2 & Glycolamide & N.D. & N.D. & - \\
3 & Acrylonitrile & $62.4 \pm 3.4$ & $30.8 \pm 1.2$ & - \\
4 & Acetonitrile & $87.4 \pm 4.5$ & $5.7 \pm 0.42$ & - \\
5 & Phenylacetonitrile & $106 \pm 5.8$ & $100 \pm 5.4$ & - \\
6 & Mandelonitrile & $550 \pm 6.4$ & $55.0 \pm 1.3$ & $>99.9 \%(R)^{\mathrm{c}}$ \\
7 & 2-Chloromandelonitrile & $68.8 \pm 3.2$ & $67.5 \pm 2.2$ & - \\
8 & Diaminomaleonitrile & $269 \pm 7.8$ & $25.1 \pm 1.5$ & - \\
9 & Iminodiacetonitrile & N.D. & N.D. & $>99.9)^{\mathrm{c}}$ \\
\hline
\end{tabular}

Using glycolonitrile as substrate, specific activity of nitrilase in Alcaligenes sp. ECU0401 was 975 \pm $13.7 \mu \mathrm{mol} \mathrm{min} \mathrm{m}^{-1}$

N.D. not detected

${ }^{\text {a }}$ Determined by HPLC (using a $\mathrm{C}_{18}$ column)

${ }^{\mathrm{b}}$ Conversion for $24 \mathrm{~h}$

${ }^{\mathrm{c}}$ Determined by HPLC (Chiralcel OD-H) [27]

\section{Efficient Biocatalyst Recycling}

Immobilized cells are preferred in this form as they can be recycled, thereby reducing production costs. Entrapment seemed to be a better choice for immobilization [25], GA/PIE cross-linked carrageenan-immobilized cells were used for further nitrile hydrolysis. To investigate the effect of recycling on the degree of glycolonitrile conversion, biotransformation reactions were carried out both with free cells and immobilized cells in batch mode. Each time, the hydrolytic reaction was carried out for $8 \mathrm{~h}$ at $30^{\circ} \mathrm{C}$. With the increase in the number of cycles, above $50.0 \%$ conversion was achieved with free cells after 6 cycles. However, approximately $90.0 \%$ conversion was achieved with immobilized cells even after 25 cycles (Fig. 4). After 29 cycles, total biocatalyst productivity of 1,042.2 g glycolic acid per gram dry cell weight and volumetric productivity of $18.0 \mathrm{~g}$ glycolic acid/(L h) were

Fig. 3 Time course of glycolic acid producing from glycolonitrile by Alcaligenes sp. ECU0401. Symbols: triangles, $10 \mathrm{mM}$; diamonds, $50 \mathrm{mM}$; squares, $100 \mathrm{mM}$ of glycolonitrile

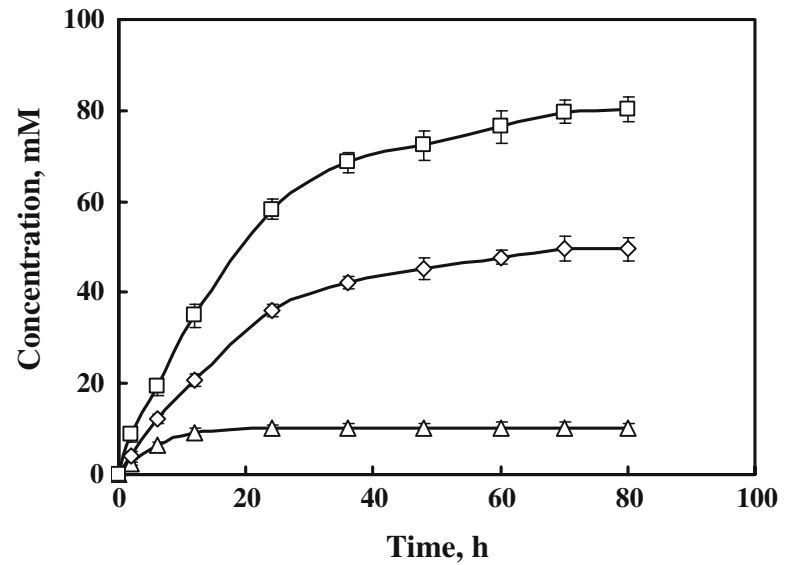


Fig. 4 Reusability of the free and immobilized cell system. Symbols: empty diamonds, free cells; filled diamonds, immobilized cells

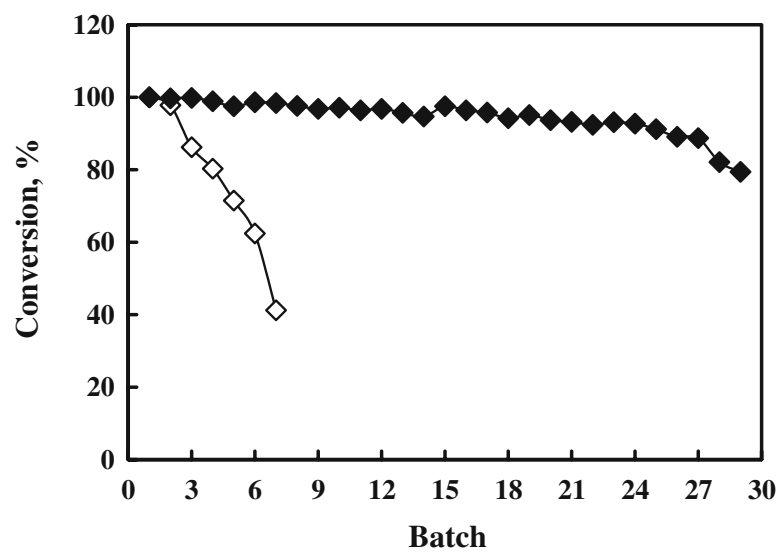

achieved using GA/PEI cross-linked carrageenan-immobilized cells. After the purification of glycolic acid from the hydrolyzates obtained from hydrolysis of glycolonitrile by immobilized cells, $0.405 \mathrm{~kg}$ of high purity $70.0 \mathrm{wt} . \%$ glycolic acid in water $(>99.0$ pure based on weight percent of organic impurities) was achieved. It appeared reasonable to suggest, therefore, that these results proved that GA/PIE cross-linked carrageenanimmobilized cells could be reused, thereby reducing the cost of biocatalysis of industrial processes, which is significant. In conclusion, the Alcaligenes sp. ECU0401 shows promise in the bioproduction of glycolic acid from glycolonitrile, although the costs of the catalyst and the product glycolic acid separation should be reduced, and in-depth exploration of this subject is needed.

\section{Conclusions}

We have successfully isolated from soil a new nitrilase-producing bacterium, Alcaligenes sp. ECU0401. After the optimization of culture conditions and reaction conditions, glycolonitrile could be effectively hydrolyze into glycolic acid by growth cells, resting cells, and immobilized cells, respectively. No glycolamide was detected in the hydrolysis of glycolonitrile, and no amidase activity was observed in hydrolyzing glycolamide. It suggested that glycolic acid produced by nitrilase mediated the transformation of glycolonitrile. The microbial nitrilase system had broad substrate specificity and exhibited high activity in the hydrolysis of aromatic and aliphatic nitriles and significantly exhibited high enantioselectivity in the hydrolysis of mandelonitrile and 2-chloromandelonitrile $(>99.9 \%$ e.e.p). GA/PIE cross-linked carrageenan-immobilized cells could be reused, and an efficient biocatalyst recycling in the production of glycolic acid was achieved with $90.0 \%$ conversion even after 25 batch recycles. After 29 cycles, total biocatalyst productivity of 1,042.2 g glycolic acid per gram dry cell weight was achieved using immobilized cells, thereby reducing the cost of biocatalysis of industrial processes, which is significant.

Acknowledgments This work was financially supported by the National Natural Science Foundation of China (nos. 20506037 and 20672037), the Ministry of Science and Technology (no. 2007AA02Z225), and the Open Project Program of the State Key Laboratory of Bioreactor Engineering, East China University of Science and Technology (no. 2008004). Cordial thanks are given to Dr. Yunhai Shi at ECUST for his kind donation of glycolonitrile. 


\section{References}

1. Liang, L. Y., Zheng, Y. G., \& Shen, Y. C. (2008). Process Biochemistry, 43(7), 758-764. doi:10.1016/j. procbio.2008.03.002.

2. Chen, J., Zheng, Y. G., \& Shen, Y. C. (2008). Process Biochemistry, 43(9), 978-983. doi:10.1016/j. procbio.2008.05.002.

3. Wang, M. X. (2005). Topics in Catalysis, 35, 117-130. doi:10.1007/s11244-005-3817-1.

4. Asano, Y., Tani, Y., \& Yamada, H. (1980). Agricultural and Biological Chemistry, 44, 2251-2252.

5. Zhu, D., Mukherjee, C., Yang, Y., Rios, B. E., Gallagher, D. T., Smith, N. N., et al. (2008). Journal of Biotechnology, 133, 327-333. doi:10.1016/j.jbiotec.2007.10.001.

6. Shi, Y. H., Sun, H. Y., Lu, D. M., Le, Q. H., Chen, D. X., \& Zhou, Y. C. (2006). Separation and Purification Technology, 49(1), 20-26. doi:10.1016/j.seppur.2005.08.002.

7. DiCosimo, R., Payne, M.S., Panova, A., Thompson, J., \& O'Keefe, D.P.(2007). U.S. Patent, 7,198,927.

8. Ebmeyer, F., Haberlein, H., Haberlein, H.H., Haberlein, J.T., Haberlein, M.C., \& Mohn, H.(1998). U.S. Patent, 5,723,662.

9. Hu, J. G., Wang, Y. J., Zheng, Y. G., \& Shen, Y. C. (2007). Enzyme and Microbial Technology, 41, 244249. doi:10.1016/j.enzmictec.2007.01.014.

10. Gavagan, J.E., Chauhan, S., DiCosimo, R., Fallon, R.D., \& Gavagan, J.E.Payne, \& M.S. (2002). U.S. Patent. USP 6,416,980.

11. Xue, J.P., Luo, J.X., Li, H.B., Yu, J.H., Zhu, J., Xu, H., \& Shen, Y.C.(2006). Chinese Patent, CN1772912.

12. Tamura, K. (1996). European Patent, EP0,711,836A1.

13. Yamaguchi, Y., Ushigome, M., \& Kato, T.(1998). U.S. Patent, 5,756,306.

14. Panova, A., Mersinger, L. J., Liu, Q., Foo, T., Roe, D. C., Spillan, W. L., et al. (2007). Advanced Synthesis \& Catalysis, $349(8-9), 1462-1474$. doi:10.1002/adsc.200700061.

15. Ben-Bassat, A., Walls, A. M., Plummer, M. A., Sigmund, A. E., Spillan, W. L., \& DiCosimo, R. (2008). Advanced Synthesis \& Catalysis, 350(11-12), 1761-1769. doi:10.1002/adsc.200800228.

16. Wu, S. J., Fogiel, A. J., Petrillo, K. L., Jackson, R. E., Parker, K. N., Parker, K. N., et al. (2008). Biotechnology and Bioengineering, 99(3), 717-720. doi:10.1002/bit.21643.

17. He, Y. C., Xu, J. H., Xu, Y., Ouyang, L. M., \& Pan, J. (2007). Chinese Chemical Letters, 18, 677-680. doi:10.1016/j.cclet.2007.04.034.

18. Chen, S. P., Huang, T., \& Sun, S. G. (2005). Journal of Chromatography. A, 1089, $142-147$. doi:10.1016/j.chroma.2005.06.076.

19. Fawcett, J. K., \& Scott, J. E. (1960). Journal of Clinical Pathology, 13, 156-159. doi:10.1136/jep. 13.2.156.

20. Weisburg, W. G., Barns, S. M., Pelletier, D. A., \& Lane, D. J. (1991). 16 S ribosomal DNA amplification for phylogenetic study. Journal of Bacteriology, 173, 697-703.

21. Zhang, Z. J., Xu, J. H., \& He, Y. C. (2008). 12th Asia Pacific Confederation of Chemical Engineering Congress, 4, 232.

22. Kobayashi, M., Izui, H., Nagasawa, T., \& Yamada, H. (1993). Proceedings of the National Academy of Sciences of the United States of America, 90, 247-251. doi:10.1073/pnas.90.1.247.

23. Nagasawa, T., Kobayashi, M., \& Yamada, H. (1998). Archives of Microbiology, 150, 89-94. doi:10.1007/BF00409723.

24. Naik, S. C., Kaul, P., Barse, B., Banerjee, A., \& Banerjee, U. C. (2008). Bioresource Technology, 99, 2631. doi:10.1016/j.biortech.2006.11.053.

25. Banerjee, A., Kaul, P., \& Banerjee, U. C. (2006). Applied Microbiology and Biotechnology, 72, $77-87$. doi:10.1007/s00253-005-0255-8.

26. Nagasawa, T., Nakamura, T., \& Yamada, H. (1990). Archives of Microbiology, 155, 13-17. doi:10.1007/ BF00291267.

27. Yamamoto, K., Oishi, K., Fujimatsu, I., \& Komatsu, K. I. (1991). Applied and Environmental Microbiology, 57, 3028-3032.

28. Nagasawa, T., Mauger, J., \& Yamada, H. (1990). European Journal of Biochemistry, 194, 765-772. doi:10.1111/j.1432-1033.1990.tb19467.x.

29. Kobayashi, M., Yanaka, N., Nagasawa, T., \& Yamada, H. (1990). Journal of Bacteriology, 172(9), 48074815.

30. He, Y. C., Xu, J. H., Pan, J., Ouyang, L. M., \& Xu, Y. (2008). Bioprocess and Biosystems Engineering, 31(5), 445-451. doi:10.1007/s00449-007-0181-5. 